\title{
Domestic Policies as Strategic Measures in Multinational Markets
}

\author{
Ali Dadpay ${ }^{1}$ \\ ${ }^{1}$ Professor of Economics, The Bill Munday School of Business, St. Edward's University, United States \\ Correspondence: Ali Dadpay, Professor of Economics, The Bill Munday School of Business, St. Edward's \\ University, 3001 South Congress Avenue, Austin, TX 78704-6489, United States. Tel: 1-512-485-4616. E-mail: \\ adadpay@stedwards.edu
}

Received: October 30, 2016

Accepted: November 21, 2016

Online Published: December 14, 2016

doi:10.5539/ijef.v9n1p1

URL: http://dx.doi.org/10.5539/ijef.v9n1p1

\begin{abstract}
This paper studies the role of privatization and subsidization policies as trade strategies in a single multinational market where private and public firms of different nationalities interact. The paper finds that when a country subsidizes its industry the rival country would have the incentive to retaliate by adopting a subsidization regime to prevent a free riders' situation from happening when said country moves to liberalize the market. However, this step does not eliminate the free rider problem governmentsare face in a market when they privatize their public firms unilaterally.
\end{abstract}

Keywords: Oligopoly, Cournot model, quantity competition, public enterprises and market performance

\section{Introduction}

The defining characteristic of mixed oligopoly markets has been the presence of a welfare-maximizing public firm competing with private profit-maximizing firms. Governments regulate their domestic markets, or respond to the actions of rival governments, by choosing the production levels of their respective public firm. This choice has allowed authors to explore the strategic interactions between governments and private sectors both in the domestic and multinational markets. Recently, several authors have studied the government's role when they can maximize their individual social welfare through a public firm and subsidization. While some authors have studied multinational mixed oligopoly markets and some have studied subsidization in mixed oligopoly markets, few have studied subsidization and its consequences in multinational markets. This paper is the first, to the best of the author's knowledge, to investigate a multinational mixed oligopoly market.

Initially introducedoriginally by Merrill and Schneider (1966), mixed oligopoly analysis was used to study the interactions between the public sector and private firms in domestic markets. Since then, its applications have been growing steadily from the study of domestic mixed oligopoly markets (Harris \& Wiens, 1980; Sertel, 1988; Cremer, Marchand, \& Thisse, 1989, 1991; DeFraja \& Delbono, 1989, 1990; Fershtman, 1990; Nilssen \& Sorgard, 2002; Matsumura \& Kanada, 2005), to analysing the role of foreign competition in such markets (Fjell \& Pal, 1996; Pal \& White, 1998; Fjell \& Heywood, 2002; Heywood \& Ye, 2010). Recently, a growing number of authors have used a mixed oligopoly structure to study multinational markets (Pal \& White, 2003; Dadpay \& Heywood, 2006; Heywood \& Ye, 2009; Dadpay, 2010). It is well established that in a multinational mixed oligopoly, governments utilize their public firms to react strategically to their rivals' actions and policies.

The policy implications remain at best ambiguous. Dadpay and Heywood (2006) demonstrate how in a single multinational mixed oligopoly market, governments face a prisoner's dilemma. Any unilateral attempt to liberalize markets would improve the rival country's social welfare while advancing the global welfare. Heywood and Ye (2009), who study the role of timing, discover that for all endogenousthatly emerged timings, privatization will always lower domestic welfare, but its influence on global welfare is ambiguous. Dadpay (2010) demonstrates that the government's emphasis on producer surplus might discourage them from joining a coordinated privatization process with other governments. Thus, governments do not always face a prisoners dilemma in privatizing their national firms as previously suggested. The same can be said when a government has already subsidized its industry (Dadpay, 2007).

Several authors have studied the consequences of subsidization in a mixed oligopoly market. Pal and White (1998), Poyago-Theotoky (2001), Fjell and Heywood (2002), Myles (2002) show that in domestic mixed oligopoly markets, subsidization would achieve the first-best pricing. However, in a multinational mixed 
oligopoly market, when a government implements subsidization, to evade the prisoner's dilemma in privatization (Dadpay \& Heywood, 2006), subsidization does not achieve first-best pricing (Dadpay, 2008).

These findings inspire this question: "Facing rivals who have implemented subsidization, would a country have the incentive to retaliate by subsidizing its industry?" This question becomes more significant during the process of globalization. Globalization has brought into close contact, governments with different approaches to industry and production. Would free market-oriented governments adopt subsidization or similar policies interacting with the governments that traditionally support the local industries through subsidization?

The present article studies a single multinational mixed oligopoly market where consumers of different nationalities share the consumers' surplus, and private firms of different nationalities maximize their profits. It assumes the market shares to be exogenous because the size of the consumers' populations varies across the various countries. In the first stage, governments choose a subsidy rate to maximize their social welfares. Then, private and public firms move simultaneously to maximize their objective functions. The paper finds that the governments could improve their social welfare by privatizing their national firms unilaterally by adjusting the optimal subsidy rate to prevent welfare loss. Privatization does not eliminate the prisoners' dilemma, which was originally suggested by Dadpay and Heywood (2006). A government does not have any incentive to privatize its national firms following a unilateral privatization by its rival government. Subsidization prevents a welfare loss, but it does not eliminate the free rider situation.

This article is organized into five sections. After the Introduction, the model, and the equilibrium is presented in Section 2. Section 3 analyses the equilibrium results. Section 4 examines privatization effects in this model, and Section 5 offers our conclusion.

\section{Model}

Assume that a multinational market is shared by two countries, domestic and foreign; in this market are one domestic public firm, one foreign public firm, $m$ domestic private firms and $n$ foreign private firm. It is assumed that all firms produce a homogenous commodity and there is a universal demand for this commodity. All firms use the same technology in producing this commodity, so the cost structure is the same for all of the firms. Several authors (Pal \& White, 1998; Fjell \& Heywood, 2002; Dadpay \& Heywood, 2006) have used quadratic cost functions to study mixed oligopoly markets:

$$
C(q)=.5 k q^{2}+f \rightarrow M C=k q, \frac{\partial^{2} C}{\partial q^{2}}
$$

The quadratic cost function allows a linear marginal cost with slope $k>0$.

Private firms maximize profits, and public firms maximize the social welfare functions of their respective societies. The government pays subsidies to both private and public firms. These subsidies are proportional to the firm's outputs. In the existing mixed oligopoly literature, authors usually assume subsidies are proportional to the firm's outputs (White, 1996; Poyago-Theotoky, 2001; Myles, 2002; Fjell \& Heywood, 2002). Thus, the total subsidy that a firm receives are a linear function of its output:

$$
\begin{aligned}
& S_{d}=s_{d} * q_{i}^{d} \\
& S_{f}=s_{f} * q_{j}^{f}
\end{aligned}
$$

Where $s_{d}$ is the domestic subsidy rate and $s_{f}$ is the domestic subsidy rate. Demand in the market is linear and can be written as:

$$
P=a-\left(q_{o}^{d}+q_{o}^{f}+\sum_{i=1}^{m} q_{i}^{d}++\sum_{j=1}^{n} q_{j}^{f}\right)
$$

In (3), $P$ is price, $q_{o}^{d}$ is the domestic public firm's output, $q_{o}^{f}$ is the foreign public firm's output, $q^{d}{ }_{i}$ is the domestic private firm $i$ 's output $(i=1, \ldots, m)$ and $q_{j}^{f}$ is the foreign private firm $j$ 's output $(j=1, . ., n)$. Based on the demand function, consumer surplus in this multinational market can be written as:

$$
C S=.5\left(q_{o}^{d}+q_{o}^{f}+\sum_{i=1}^{m} q_{i}^{d}++\sum_{j=1}^{n} q_{j}^{f}\right)^{2}
$$

Using equation (4), domestic consumers' surplus and foreign consumer surplus are defined as:

$$
\begin{gathered}
C S_{d}=.5 \theta\left(q_{o}^{d}+q_{o}^{f}+\sum_{i=1}^{m} q_{i}^{d}++\sum_{j=1}^{n} q_{j}^{f}\right)^{2} \\
C S_{f}=.5(1-\theta)\left(q_{o}^{d}+q_{o}^{f}+\sum_{i=1}^{m} q_{i}^{d}++\sum_{j=1}^{n} q_{j}^{f}\right)^{2}
\end{gathered}
$$

where $\theta$ is the domestic customers' share of consumer surplus, to which this article also refers to market share. 
Since the domestic and the foreign governments subsidize their industries, firm's profit functions include subsidy rate as an exogenous parameter.

Public domestic firm profit is as follows:

$$
\pi_{o}^{d}=P q_{o}^{d}-f-.5 k q_{o}^{d^{2}}+s_{d} q_{o}^{d}
$$

Private domestic firm profit function is as follows:

$$
\pi_{i}^{d}=P q_{i}^{d}-f-.5 k q_{i}^{d^{2}}+s_{d} q_{i}^{d} \quad(i=1, \ldots, m)
$$

Foreign public firm profit function is as follows:

$$
\pi_{o}^{f}=P q_{o}^{f}-f-.5 k q_{o}^{f^{2}}+s_{f} q_{o}^{f}
$$

Foreign private firm profit function is as follows:

$$
\pi_{j}^{f}=P q_{j}^{f}-f-.5 k q_{j}^{f^{2}}+s_{f} q_{j}^{f} \quad(j=1, \ldots, n)
$$

The introduction of subsidy also changes the social welfare function in the domestic country. Its social welfare function is written as the sum of consumer surplus and total profits and because a subsidy is paid, it must be deducted from the total. The domestic social welfare function and the foreign social welfare are written as follows:

$$
\begin{gathered}
W_{d}=.5 \theta\left(q_{o}^{d}+q_{o}^{f}+\sum_{i=1}^{m} q_{i}^{d}++\sum_{j=1}^{n} q_{j}^{f}\right)^{2}+\pi_{o}^{d}+\sum_{i=1}^{m} \pi_{i}^{d}-s_{d}\left(q_{o}^{d}+\sum_{i=1}^{m} q_{i}^{d}\right) \\
W_{f}=.5(1-\theta)\left(q_{o}^{d}+q_{o}^{f}+\sum_{i=1}^{m} q_{i}^{d}++\sum_{j=1}^{n} q_{j}^{f}\right)^{2}+\pi_{o}^{f}+\sum_{j=1}^{n} \pi_{j}^{f}-s_{f}\left(q_{o}^{f}+\sum_{j=1}^{n} q_{j}^{f}\right)
\end{gathered}
$$

Assuming those governments have set the subsidy rate in the first stage, private and public firms move simultaneously to choose their outputs. Private firms maximize their profits, and public firms maximize the social welfare in a Cournot game. Solving the ensuing first order condition's equations yields the following results.

Domestic private firm's equilibrium:

$$
q_{i}^{d^{*}}=\frac{a k(k+1)+s_{d}(k+1)(k+2)+n k\left(s_{d}-s_{f}\right)}{(k+1)\left(k^{2}+m k+n k+3 k+2\right)}
$$

Foreign private firm's equilibrium:

$$
q_{j}^{f^{*}}=\frac{a k(k+1)+s_{f}(k+1)(k+2)+m k\left(s_{f}-s_{d}\right)}{(k+1)\left(k^{2}+m k+n k+3 k+2\right)}
$$

Domestic public firm's equilibrium output:

$$
q_{o}^{d^{*}}=\frac{(k+1)\left\{a \theta[k(m+n+2)+2]+a k(k+1-m)-s_{d} m(k+2)-k(1-\theta)\left(m s_{d}+n s_{f}\right)\right\}-m n k\left(s_{d}-s_{f}\right)}{(k+1)\left[k^{2}(k-1)+k(k+1)(m+n+5)+2\right]}
$$

Foreign public firm's equilibrium output:

$$
q_{o}^{f^{*}}=\frac{(k+1)\left\{a m k(1-\theta)-s_{f} n(k+2)-k \theta\left(m s_{d}+n s_{f}\right)\right\}+a[2(1-\theta)(1-2 k)-\theta n k]+m n k\left(s_{d}-s_{f}\right)}{(k+1)\left[k^{2}(k-1)+k(k+1)(m+n+5)+2\right]}
$$

Equilibrium total output:

$$
Q^{*}=\frac{2 a+k\left(m s_{d}+n s_{f}\right)+a k(m+n+2)}{\left(k^{2}+m k+n k+3 k+2\right)}
$$

Equilibrium price:

$$
P^{*}=\frac{k\left[a(k+1)-\left(m s_{d}+n s_{f}\right)\right]}{\left(k^{2}+m k+n k+3 k+2\right)}
$$

Firms' outputs in social welfare functions are substituted with their equilibrium values. Governments maximize the new presentations of social welfare functions on subsidy rates. Solving first order conditions, one can derive governments' subsidization best response functions. The optimal domestic and foreign subsidy rates are derived by substituting best response functions. The optimal subsidy rates are illustrated as follows:

$$
\begin{aligned}
& s_{d}^{*}=h(a, k, m, n, \theta)=a \frac{A_{6}^{\prime} k^{6}+A_{5}^{\prime} k^{5}+A_{4}^{\prime} k^{4}+A_{3}^{\prime} k^{3}+A_{2}^{\prime} k^{2}+A_{1}^{\prime} k+A_{0}^{\prime}}{B_{6}^{\prime} k^{6}+B_{5}^{\prime} k^{5}+B_{4}^{\prime} k^{4}+B_{3}^{\prime} k^{3}+B_{2}^{\prime} k^{2}+B_{1}^{\prime} k+B_{0}^{\prime}} \\
& s_{f}^{*}=g(a, k, m, n, \theta)=a \frac{A_{6}^{\prime \prime} k^{6}+A_{5}^{\prime \prime} k^{5}+A_{4}^{\prime \prime} k^{4}+A_{3}^{\prime \prime} k^{3}+A_{2}^{\prime \prime} k^{2}+A_{1}^{\prime \prime} k+A_{0}^{\prime \prime}}{B_{6}^{\prime \prime} k^{6}+B_{5}^{\prime \prime} k^{5}+B_{4}^{\prime \prime} k^{4}+B_{3}^{\prime \prime} k^{3}+B_{2}^{\prime \prime} k^{2}+B_{1}^{\prime \prime} k+B_{0}^{\prime \prime}}
\end{aligned}
$$


where $A_{0}$ through $B_{6}$ " are complicated functions of the number of firms, market share, the slope of marginal cost and demand; $m, n, \theta, k \& a$. Assuming that there are one domestic private firm and one foreign private firm in the market, $m=1$ and $n=1$, and these expressions can be rewritten as follows:

$$
\begin{gathered}
S_{d}^{*}=a \frac{(4 \theta-1) k^{4}-\left(4 \theta^{2}-22 \theta+3\right) k^{3}-\left(6 \theta^{2}-42 \theta+5\right) k^{2}-\left(2 \theta^{2}-32 \theta+2\right) k+8 \theta}{k^{5}+11 k^{4}+43 k^{3}+2 k^{2}(k+1) \theta(\theta-1)+72 k^{2}+58 k+16} \\
S_{f}^{*}=a \frac{(3-4 \theta) k^{4}-\left(4 \theta^{2}+14 \theta-15\right) k^{3}-\left(6 \theta^{2}+30 \theta-31\right) k^{2}-\left(2 \theta^{2}+28 \theta-28\right) k+8(1-\theta)}{k^{5}+11 k^{4}+43 k^{3}+2 k^{2}(k+1) \theta(\theta-1)+72 k^{2}+58 k+16}
\end{gathered}
$$

Plugging in the optimal subsidy rates in the equilibrium, as described by equations 13 to 18 yields the equilibrium values. This new presentation of the equilibrium in a multinational mixed oligopoly market provides new insights into government incentives and private firm's profit-maximizing behavior. The next section analyses this new equilibrium in which countries use their public firms as well as subsidization to engage each other strategically.

\section{Equilibrium Analysis}

The present study departs from the existing literature by assuming a more complex model, in which industries are subsidized, and governments set both subsidy rates and public firm's outputs to maximize social welfare. While the model captures the reality of markets more thoroughly than previously studied models, it is har der to interpret. However, such complexity is not rare in the mixed oligopoly literature. Facing challenging situations, different authors have adopted different approaches. Pal and White (2003) base their conclusions on assuming one private and one public firm in the market while Dadpay and Heywood (2006) and Dadpay (2010) use numerical simulations to analyze market dynamics with different numbers of foreign and domestic private firms. In analyzing the equilibrium results, this paper adopts the approach of Pal and White (2003) to develop some insights into market dynamics. Studying privatization effects in the next section, it adopts Dadpay and Heywood's (2006) numerical simulation approachorder to identify the effects of privatization in different market structures.

Proposition 3.1. The difference between domestic and foreign firms' outputs, both public and private, is proportional to the difference of subsidy rates they receive.

Proof. Substituting $s_{d}$ and $s_{f}$ by their optimal values from equations (21) and (22) yields the following for $m=1$ and $n=1$ :

$$
\begin{aligned}
& s_{d}^{*}-s_{f}^{*}=\frac{(2 \theta-1)(k+1)(2 k+1)\left(k^{2}+3 k+4\right)}{k^{5}+11 k^{4}+43 k^{3}+72 k^{2}+58 k+16-2 \theta(1-\theta) k^{2}(k+1)} \\
& q_{o}^{d^{*}}-q_{o}^{f^{*}}=\frac{(2 \theta-1)(k+1)\left(k^{2}+4 k+2\right)}{k^{5}+11 k^{4}+43 k^{3}+72 k^{2}+58 k+16-2 \theta(1-\theta) k^{2}(k+1)} \\
& q_{i}^{d^{*}}-q_{j}^{f^{*}}=\frac{(2 \theta-1)(2 k+1)\left(k^{2}+3 k+4\right)}{k^{5}+11 k^{4}+43 k^{3}+72 k^{2}+58 k+16-2 \theta(1-\theta) k^{2}(k+1)}
\end{aligned}
$$

It must be noted that similar formulas can be derived for other combinations of $m$ and $n$. It can be shown that the difference between private firms and the difference between public firms both are linear functions of the difference of optimal subsidy rates:

$$
\begin{aligned}
& q_{o}^{d^{*}}-q_{o}^{f^{*}}=\frac{\left(s_{d}^{*}-s_{f}^{*}\right)}{(2 k+1)} \\
& q_{i}^{d^{*}}-q_{j}^{f^{*}}=\frac{\left(s_{d}^{*}-s_{f}^{*}\right)}{(k+1)}
\end{aligned}
$$

Proposition 3.1 shows that the general asymmetry in the market, as suggested by Dadpay and Heywood (2006), does not hold in this market structure. However, that symmetry exists under one specific condition, as described by Proposition 3.2.

Proposition 3.2. If the ratio of countries' shares of consumers' surplus is equal to the ratio of the number of their firms, then the optimal subsidy rate does not change from one country to the other.

Proof. In equation (23), if $\theta=0.5$, the domestic optimal subsidy rate equals the foreign optimal subsidy rate. This can be extended to the following condition:

$$
\frac{1-\theta}{\theta}=\frac{n+1}{m+1} \rightarrow s_{d}^{*}=s_{f}^{*}
$$


Should this ratio hold in any market structure, the optimal domestic subsidy will equal to the foreign one. This result is confirmed for any combination $m$ and $n$ as well as solving for the model when $\theta=(m+1) /(m+n+2)$.

This finding is most intuitive since it shows that the symmetry suggested by the previous authors could exist despite subsidization. Thus, the private firms would produce the same output independent of their nationality as suggested by Dadpay and Heywood (2006). However, this goes further in the case of this study because public firms also produce the same output independent of their nationality. This finding departs from Dadpay and Heywood (2006) and indicates that symmetry in subsidized multinational markets is not the outcome of competition but the result of market structure. The governments' decision to subsidize their industries makes the profit-maximizing private firm conscious of its country's market share. This decision explains the similarities between governments' subsidization policies when their population's share of consumer surplus is equal to their industry's share of production in regional markets. A good example is a similarity between fuel pricing policies in Persian Gulf countries with similar population size and oil production capacity.

Proposition 3.3. When both governments use subsidization as a strategic trade instrument, the domestic public firm always decreases its output in response to a domestic private firm's entry while it increases its output in response to a foreign private firm's entry if $\theta$ is above a critical level.

Proof. Solving the model, the equilibrium values are derived for $m=1$ and $n=1$ to provide the benchmark. Then, the equilibrium is estimated for $m=1$ and $n=2$ for a foreign private firm's entry and for $m=2$ and $n=1$ for a domestic private firm's entry. Estimating the size of the change in the domestic public firm's output for each case, a set of polynomials are derived, in which coefficients are functions of $\theta$ for the case of $k=1$; these changes can be written as the following:

$$
\begin{gathered}
\Delta q_{o}^{d^{*}}=q_{m=1, n=2}^{d^{*}}-q_{m=1, n=1}^{d^{*}}=-\frac{a\left(3723-7669 \theta+3140 \theta^{2}+212 \theta^{3}\right)}{\left(23 \theta^{2}+43 \theta+1044\right)\left(4 \theta^{2}-4 \theta+201\right)} \\
\Delta q_{o}^{d^{*}}=q_{o=2, n=1}^{d^{*}}-q_{o}^{d^{*}}{ }_{m=1, n=1}=-\frac{a\left(4782+16153 \theta-3896 \theta^{2}+124 \theta^{3}\right)}{\left(23 \theta^{2}+43 \theta+1044\right)\left(4 \theta^{2}-4 \theta+201\right)}
\end{gathered}
$$

Solving equations (28) and (29) for $\theta$, it is shown that equation (29) is always negative for the range of values $\theta$, and the domestic market share can have from 0 to 1 . Equation (28) is positive if $\theta$ is above a certain value. As the slope of marginal cost changes, this critical level changes, however, there is always a market share above which the domestic public firm increases its output when a foreign private firm enters the market.

Proposition 3.4. The domestic optimal subsidy rate decreases if a domestic private firm enters the market, and increases if a foreign private firm enters the market if $\theta$ is below a critical level.

Proof. Solving the model, the equilibrium values for the domestic subsidy rates are derived for $m=1$ and $n=1$ to provide the benchmark. Then, the equilibrium is estimated for $m=1$ and $n=2$ for a foreign private firm's entry and for $m=2$ and $n=1$ for a domestic private firm's entry. Estimating the size of the change in the domestic optimal subsidy rate, a set of polynomials are derived, in which coefficients are functions of $\theta$ for the case of $k=1$ these changes can be written as the following:

$$
\begin{gathered}
s_{d_{m=1, n=2}}^{*}-s_{d_{m=1, n=1}}^{*}=\frac{a\left(4449-1589 \theta-3650 \theta^{2}+420 \theta^{3}+88 \theta^{4}\right)}{\left(23 \theta^{2}+43 \theta+1044\right)\left(4 \theta^{2}-4 \theta+201\right)} \\
s_{d_{m=2, n=1}}^{*}-s_{d_{m=1, n=1}}^{*}=-\frac{a\left(7086+21985 \theta-9384 \theta^{2}+1364 \theta^{3}-48 \theta^{4}\right)}{\left(23 \theta^{2}-89 \theta+1110\right)\left(4 \theta^{2}-4 \theta+201\right)}
\end{gathered}
$$

Solving equations (30) and (31) for $\theta$, it is shown that equation (30) is always positive for the range of values $\theta$, and domestic market share can have from 0 to 1 . However, equation (31) is always negative for all values of $\theta$. For all other values of $k$, the slope of marginal cost holds for this argument, since those values are positive and the sign of expressions depends on the values of $\theta$.

Propositions 3.3 and 3.4 summarize the effects of entry into the market; they demonstrate that governments respond strategically to new entries using subsidization and their public firm's output. When a domestic private firm enters the market, its entry increases total output and thus improves consumers' surplus. Since the new entrant improves consumers' surplus, the government lowers the subsidy rate it pays the industry, and the domestic public firm reduces its output. This causes the equilibrium price to increase and the producers' surplus in the domestic market to improve. When a foreign private firm enters the market, the foreign producer's surplus increases and thus the domestic government increases the subsidy rate to improve the domestic social welfare through consumers' surplus. Surprisingly, the optimal subsidy rate reacts to the new entry in the same way that the public firms respond to the new entry. Dadpay and Heywood (2006) demonstrate that the entry of a domestic private firm causes the output of the domestic public firm to decrease and entry of a foreign private firm causes 
the output of the domestic public firm to decrease. The present study confirms that in a mixed oligopoly market, governments use the means at their disposal to maximize their social welfare either through producers' surplus or consumers' surplus or both. It also shows that despite subsidization, the government still benefits from having a public firmorder to guarantee a high level of social welfare in its respective society. The question is if both countries benefit from a simultaneous liberalization of the market, as suggested by Dadpay and Heywood (2006). The next section summarizes the effects of privatization in this market.

\section{Privatization}

This section reviews the consequences of unilateral and simultaneous privatization in a single market of multinational mixed oligopolies where both governments are subsidizing their respective industries. It analyses the changes in optimal subsidy rates and social welfare levels as governments liberalize their industries, either unilaterally or simultaneously. There is symmetry in the market, in that both governments use subsidization and both countries have public firms. We already know that both governments utilize subsidization as a strategic trade instrument. This paper determines the directions of change for different combinations of numbers of private domestic and foreign firms, $m \& n$, at different values of market share $(\theta=0, .25, .5, .75,1)$, to study the effects of privatization in this market structure. The effects of privatization process are captured through estimating the difference of equilibrium values, as follows:

In the case of domestic unilateral privatization:

$$
\begin{gathered}
\Delta s_{i}^{*}=s_{i_{d p r i v}}^{*}-s_{i}^{*}, \quad i=f \text { or } d \\
\Delta W_{i}^{*}=W_{i_{d p r i v}^{*}}^{*}-W_{i}^{*}, i=\text { for } d
\end{gathered}
$$

And in the case of simultaneous privatization:

$$
\begin{aligned}
\Delta s_{i}^{*} & =s_{i_{s i m}}^{*}-s_{i}^{*}, \quad i=f \text { or } d \\
\Delta W_{i}^{*} & =W_{i_{s i}}^{*}-W_{i}^{*}, \quad i=f \text { or } d
\end{aligned}
$$

Since the equilibrium values for optimal subsidy rates and social welfares are complicated mathematical models, I utilize numerical simulations to study these changes. In these simulations, $a=1 \& k=1$ with different combinations of $m \& n$ from 1 to 5 and different values of $\theta=0, .25, .5, .75$ and 1 are used to calculate the size of changes and to determine their signs. The results are presented in Tables 1 to 6 and propositions 4.1 through 4.3 offer conclusions based on these results.

The results in Table 1 show that any government that carries on unilateral privatization pays an increased subsidy rate and its individual welfare improves as well asof its rival country, where the optimal subsidy rate declines. As one may observe for any given number of domestic private firms and foreign ones, the domestic government increases the optimal subsidy rate it pays the domestic firms. Although, when the number of foreign private firms in the market is large, the size of the increase in the optimal subsidy rate is smaller, nonetheless for the domestic social welfare to improve, the optimal subsidy rate must increase. It must be pointed out that the increase in the optimal subsidy rate is increasing iton the domestic share of consumers' surplus. The larger the domestic customer's share of the market is, the larger the increase in the optimal subsidy rate must be.

When a government privatizes its public firms, total output in the market declines and thus the equilibrium price increases. The domestic government pays a higher subsidy rate to lower prices and to maximize social welfare through consumer surplus as well. A significant share of market amplifies the significance of consumers' surplus in the domestic social welfare. This share results in an even larger increase in the optimal subsidy rate.

Proposition 4.1. When both governments use subsidization as a strategic trade instrument, and one privatizes unilaterally, the other has no incentive to follow its example.

Proof. The results of simulations for equations (33) and (35) are reported in Tables 2 and 3, while Tables 5 and 6 report the consequences of simultaneous privatization on domestic and foreign social welfare levels. The social welfare increases in both countries in both unilateral and simultaneous privatization. However, in most cases, when the domestic government privatizes unilaterally, foreign social welfare improves more than domestic social welfare.

The social welfare improves in both countries as a result of simultaneous privatization, as demonstrated in Tables 5 and 6 . However, the foreign social welfare increases less than the case where the domestic government liberalizes its public firm unilaterally. Thus, it is less likely that the foreign government will follow the domestic country in privatizing its public firm. Such a step causes foreign social welfare to decline from its newly achieved level.

Proposition 4.2. When governments decide to privatize simultaneously, the government whose own population 
share of the market is smaller than its rival increases the optimal subsidy rate while its rival decreases the optimal subsidy rate.

Proof. Table 4 presents the results of numerical simulations of the effects of simultaneous privatization. The domestic government increases the optimal subsidy rate when $\theta<0.5$ and reduces it when $\theta>0.5$. The foreign government follows the same path when $1-\theta<0.5$ and $1-\theta>0.5$. Thus, when the domestic government reduces the optimal subsidy rate, the foreign government increases the optimal subsidy rate.

When the domestic country share of the market is small, the domestic government seeks to increase social welfare by increasing its respective producers' surplus. Increases in the optimal subsidy rate give domestic private firms a comparative advantage over their foreign rivals so they can produce more. At the same time, the foreign government reduces the optimal subsidy rate. The foreign country's citizens are benefiting from the increase in subsidies paid by the domestic government, so the foreign consumers' surplus is already improved.

Proposition 4.3. If countries' share of consumer surplus equals their share of production, then either unilateral or simultaneous privatization does not alter either their welfare or optimal subsidy rate.

Proof. When countries' share of consumers' surplus equals their share of production, the loss in consumers' surplus is compensated by their gain in producers' surplus and vice versa. Thus, the privatization process, which usually results in reduced consumers' surplus and increased producers' surplus, does not increase the producers' surplus more than the fall in the consumers' surplus. This can be shown by solving the model with:

$$
\frac{1-\theta}{\theta}=\frac{n+1}{m+1}
$$

The consequences of privatization change when both governments exercise subsidization. First, both countries can gain from their rival's unilateral privatization, but the country that carries it on has no choice but to pay an increased optimal subsidy rate to improve its welfare, while its rival can pay a reduced optimal subsidy rate. Neither country has any incentive to privatize when its rival privatizes unilaterally. Thisactually causes its welfare to decline and for its gains to be lost. Thus, the free rider problem continues to exist even when both governments are paying subsidies to their respective industries.

\section{Conclusion}

This study answers the question asked in the beginning, "Would a government adopt subsidization when it engages a rival government that has already adopted this policy?" The answer is yes. By subsidizing foreign firms, the foreign government prevents the loss of welfare to the domestic country when it liberalizes its industry unilaterally. However, the government, which carries on a unilateral privatization, has to increase the subsidy rate its pays its respective industry. The free rider issue continues to exist in multinational mixed oligopoly markets, although not in the form of welfare loss. Both countries benefit most when the other carries on a unilateral privatization. The symmetry in the market is created structurally and not by competing for private firms seeking to maximize their profits as suggested by previous studies. The perfect symmetry exists where a country's share of consumers' surplus equals its share of production. In this market, neither government has any incentive to liberalize its markets.

Further studies should investigate if governments adopt other forms of policies already adopted by their rivals in a single multinational market. Mixed oligopoly analysis offers an intuitive way to study and to understand the market dynamics between competing governments interacting with their private firms.

Table 1. Domestic privatization effects on the domestic \& foreign optimal subsidy rates $\left(s_{d}{ }^{*} \& s_{f}{ }^{*}\right)$ for $(a=1, k=1$, $\theta=0, .25, .5, .75,1)$ (Case retaliation)

\begin{tabular}{|c|c|c|c|c|c|c|}
\hline$N$ & & 1 & 2 & 3 & 4 & 5 \\
\hline \multirow{3}{*}{1} & $\Delta \mathrm{sd}^{*}$ & $.07, .12, .2, .36, .57$ & $.08, .12, .2, .28, .42$ & $.08, .11, .16, .23, .33$ & $.08, .1, .14$ & $.08, .09, .12, .15, .2$ \\
\hline & $\Delta \mathrm{sf}^{*}$ & $2,-.03,-.03,-.02,004$ & $2,-.04,-.04,-.04,-.03$ & $1,-.04,-.05,-.05,-.04$ & 001.-.04,-..05,-.06,-..06 & $-.01,-.04,-.06,-.07,-.07$ \\
\hline & $\Delta \mathrm{sd}^{*}$ & $.05, .1, .2, .35$ & $.06, .1, .18, .2$ & $.07, .1, .16, .2$ & $.07, .1, .14$, & .07, \\
\hline \multirow[t]{2}{*}{2} & $\Delta \mathrm{sf}^{*}$ & $-.02,-.02,-.02,-.01,-.01$ & $-.01,-.02,-.03,-.02,-.01$ & $-.01,-.02,-.03,-.03,-.03$ & $-.003,-.02,-.03,-.04,-.04$ & -.002,-.02,-.04,-..04,-..05 \\
\hline & $\Delta \mathrm{sd}^{*}$ & $.03, .1, .2, .3$ & $. .17, .2$ & $.15, .2$ & 26 & .07 \\
\hline \multirow[t]{2}{*}{3} & $\Delta \mathrm{sf}^{*}$ & $-.01 .-.02,-.01,-.01,-.01$ & $-.01,-.01,-.02,-.01,-.005$ & $-.003,-.01,-.02,-.02,-.02$ & $-.001,-.01,-.02,-.03,-.03$ & $.001,-.01,-.02,-.03,-.03$ \\
\hline & $\Delta \mathrm{sd}^{*}$ & $.02, .1, .18,33, .56$ & $.04, .09, .16, .26, .41$ & $.05, .09, .14, .22, .32$ & $.06, .09, .13, .19, .26$ & $.06, .09, .12, .16, .22$ \\
\hline \multirow[t]{2}{*}{4} & $\Delta \mathrm{sf}^{*}$ & -.01,-..01,-.01,-.004,-.01 & $-.01,-.01,-.01,-.01,-.02$ & $-.002,-.01,-.01,-.01,-.01$ & $.001,-.01,-.02,-.02,-.02$ & $.002,-.01,-.02,-.02,-.02$ \\
\hline & $\Delta \mathrm{sd}^{*}$ & $.01, .1, .17, .32, .56$ & $.04, .08, .15, .26, .4$ & $.05, .09, .14, .21, .31$ & $.05, .08, .13, .18, .26$ & $.06, .08, .12, .16, .22$ \\
\hline 5 & $\Delta \mathrm{sf}^{*}$ & $-.01,-.01,-.01,-.003, .01$ & -.005,-.008,-.009,-.007,0 & $-(.001, .006, .01, .01, .007)$ & $.002,-.005,-.01,-.01,-.01$ & .004,-.005,-.01,-.02,-.02 \\
\hline
\end{tabular}


Table 2. Domestic privatization effects on domestic welfare $(a=1, k=1, \theta=0, .25, .5, .75,1)$

\begin{tabular}{|c|c|c|c|c|c|}
\hline $\mathbf{M} \mathbf{N}$ & $\mathbf{1}$ & 2 & 3 & 4 & 5 \\
\hline $\mathbf{1}$ & $+,+, \mathbf{0},+,+$ &,,,,++++ .002 &,,,,++++ .002 & $+,+,+, .001, .003$ & $+, \mathbf{0},+, .001, .003$ \\
\hline 2 &,,,,+++++ & $+,+, \mathbf{0},+, .001$ &,,,,++++ .001 &,,,,++++ .002 &,,,.,++++ .002 \\
\hline 3 &,,,,+++++ &,,,,+++++ & $+,+, \mathbf{0},+,+$ &,,,,+++++ &,,,,++++ .001 \\
\hline 4 &,,,,+++++ &,,,,++++ .002 &,,,,++++ .002 & $+,+, \mathbf{0},+,+$ &,,,,++++ .001 \\
\hline 5 & $+,+,+, \mathbf{0},+$ &,,,,+++++ &,,,,+++++ &,,,,+++++ & $+,+, \mathbf{0},+,+$ \\
\hline
\end{tabular}

Note. + stands for a very small but positive number, numbers larger than .001 are reported.

Table 3. Domestic privatization effects on the foreign welfare $(a=1, k=1, \theta=0, .25, .5, .75,1)$

\begin{tabular}{rrccccc}
\hline $\mathbf{M}$ & $\mathbf{N}$ & $\mathbf{1}$ & $\mathbf{2}$ & $\mathbf{3}$ & $\mathbf{4}$ & \\
\hline $\mathbf{1}$ & & $+,+, \mathbf{0}, .001, .005$ & $+,+,+, .002, .007$ & $.001,+,+, .003, .01$ & $.001,+,+, .004, .01$ & $.001, \mathbf{0},+, .005, .01$ \\
$\mathbf{2}$ & $.001,+,+,+, .002$ & $.001,+, \mathbf{0},+, .004$ & $.001,+,+, .001, .005$ & $.001,+,+, .006, .002$ & $.001,+,+, .003, .007$ \\
$\mathbf{3}$ & $.001,+,+,+, .001$ & $.002,+,+,+, .003$ & $.001,+, \mathbf{0},+, .002$ & $.002,+,+,+, .004$ & $.001,+,+, .002, .005$ \\
$\mathbf{4}$ & $.001,+,+,+, .001$ & $.001,+,+,+, .002$ & $.002,+,+,+, .002$ & $+,+, \mathbf{0},+,+$ & $.001,+,+,+, .004$ \\
$\mathbf{5}$ & $.002,+,+, \mathbf{0},+$ & $.002,+,+,+, .001$ & $.002,+,+,+, .002$ & $.002,+,+,+,+$ & $.002,+, \mathbf{0},+, .003$ \\
\hline
\end{tabular}

Table 4. Simultaneous privatization effects on the domestic $\&$ foreign optimal subsidy rates $\left(s_{d}{ }^{*} \& s_{f}{ }^{*}\right)$ for $\quad(a=$ $1, k=1, \theta=0, .25, .5, .75,1)$ (Case Retaliation)

\begin{tabular}{|c|c|c|c|c|c|c|}
\hline$M^{N}$ & & 1 & 2 & 3 & 4 & 5 \\
\hline \multirow{3}{*}{1} & $\Delta s_{d}{ }^{*}$ & $.05, .02, \mathbf{0},-.01,-.02$ & $.05, .02,-.01,-.03,-05$ & $.04, .01,-,-.04,-.06$ & $.04,+,-.02,-.05,-.07$ & $.04, \mathbf{0},-,-,-.08$ \\
\hline & $\Delta s_{f}{ }^{*}$ & $-.02,-.01, \mathbf{0}, .02, .05$ & $-.01,-,+, .02, .05$ & $-,-,+, .02, .04$ & $-,-,+, .02, .03$ & $-\quad, \mathbf{0}, \quad+, .02, .03$ \\
\hline & $\Delta s_{d}{ }^{*}$ & $.05, .02,+,-,-$ & $.04, .02, \mathbf{0},-.02,-.02$ & $.04, .02,-,-.02,-.03$ & $.04, .01,-.01,-.03,-.04$ & $.04,+,-.02,-.04,-.05$ \\
\hline \multirow[t]{2}{*}{2} & $\Delta s_{f}^{*}$ & $-.04,-.03,-,+, .05$ & $-.02,-.01, \mathbf{0}, .02, .04$ & $-.01,-,+, .02, .04$ & $-,-,+, .02, .04$ & $-,-,+, .02, .03$ \\
\hline & $\Delta s_{d}{ }^{*}$ & $.04, .02,+,-,-$ & $.04, .02,+,-,-.01$ & $.04, .02, \mathbf{0},-.01,-.02$ & $.04, .02,-,-.02,-.03$ & $.03, .01,-,-.02,-.04$ \\
\hline \multirow[t]{2}{*}{3} & $\Delta s_{f}^{*}$ & $-.05,-.04,-.01, .01, .04$ & $-.04,-.02,-,+, .04$ & $-.02,-.01, \mathbf{0}, .02, .04$ & $-.02,-,+, .02, .03$ & $-.01,-,+, .02, .03$ \\
\hline & $\Delta s_{d}{ }^{*}$ & $.03, .02,+,-,-$ & $.04, .02,+,-,-$ & $.04, .02,+,-,-.02$ & $.04, .02, \mathbf{0},-.01,-.02$ & $.03, .01,-,-.02,-.03$ \\
\hline 4 & $\Delta s_{f}^{*}$ & $-.07,-.05,-.02,+, .04$ & $-.04,-.03,-.01, .01, .04$ & $-.03,-.02,-, .02, .04$ & $-.02,-.01, \mathbf{0}, .02, .03$ & $-.02,-,+, .02, .03$ \\
\hline & $\Delta s_{d}{ }^{*}$ & $.03, .02,+, \quad \mathbf{0},-$ & $.03, .02,+,-,-$ & $.03, .02,+,-,-.01$ & $.03, .02,+,-,-.02$ & $.03, .01, \mathbf{0},-.01,-.02$ \\
\hline 5 & $\Delta s_{f}^{*}$ & $-.08,-.06,-.03, \mathbf{0}, .04$ & $-.05,-.04,-.02,+, .04$ & $-.04,-.02,-,+, .03$ & $-.03,-.02,-, .01, .03$ & $-.02,-.01, \mathbf{0}, .01, .03$ \\
\hline
\end{tabular}

Table 5. Simultaneous privatization effects on domestic welfare $(a=1, k=1, \theta=0, .25, .5, .75,1)($ Case retaliation)

\begin{tabular}{|c|c|c|c|c|c|}
\hline $\begin{array}{l}\mathrm{M} \\
\mathrm{N}\end{array}$ & $\mathbf{1}$ & 2 & 3 & 4 & 5 \\
\hline 1 & $+,+, \mathbf{0},+,+$ &,,,,+++++ &,,,,++++ .01 &,,,,++++ .01 & $+, \mathbf{0},+,+, .01$ \\
\hline 2 & $.01,+,+,+,+$ & $+,+, \mathbf{0},+,+$ &,,,,+++++ &,,,,+++++ &,,,,++++ .01 \\
\hline 3 & $.01,+,+,+,+$ &,,,,+++++ & $+,+, \mathbf{0},+,+$ &,,,,+++++ &,,,,+++++ \\
\hline 4 & $.02,+,+,+,+$ & $.01,+,+,+,+$ &,,,,+++++ & $+,+, \mathbf{0},+,+$ &,,,,+++++ \\
\hline 5 & $.02,+,+, \mathbf{0},+$ & $.01,+,+,+,+$ &,,,,+++++ &,,,,+++++ & $+,+, \mathbf{0},+,+$ \\
\hline
\end{tabular}

Table 6. Simultaneous privatization effects on the foreign welfare $(a=1, k=1, \theta=0, .25, .5, .75,1)($ Case retaliation)

\begin{tabular}{|c|c|c|c|c|c|}
\hline $\mathrm{M}^{\mathrm{N}}$ & 1 & 2 & 3 & 4 & 5 \\
\hline 1 & $+,+, \mathbf{0},+,+$ &,,,,++++ .01 &,,,,++++ .01 &,,,,++++ .02 & $+, \mathbf{0},+,+, .02$ \\
\hline 2 &,,,,+++++ & $+,+, \mathbf{0},+,+$ &,,,,+++++ &,,,,++++ .01 &,,,,++++ .01 \\
\hline 3 & $.01,+,+,+,+$ &,,,,+++++ & $+,+, \mathbf{0},+,+$ &,,,,+++++ &,,,,+++++ \\
\hline 4 & $.01,+,+,+,+$ & $.01,+,+,+,+$ &,,,,+++++ & $+,+, \mathbf{0},+,+$ &,,,,+++++ \\
\hline 5 & $.01,+,+, \mathbf{0},+$ & $.01,+,+,+,+$ &,,,,+++++ &,,,,+++++ & $+,+, \mathbf{0},+,+$ \\
\hline
\end{tabular}

\section{References}

Ali, D. (2007). Three essays on applied mixed oligopoly theory and policy implications. Doctoral Dissertation, the University of Wisconsin-Milwaukee. 
Cremer, H., Marchand, M., \& Thisse, J. F. (1989). The Public Firm as an Instrument for Regulating an Oligopolistic Market†. Oxford Economic Papers, 41(2), 283-301.

Dadpay, A. (2010). Governments and Producers in Multinational Markets: A Mixed Oligopoly. Applied Economics Quarterly, 56(3), 211-229. https://doi.org/10.3790/aeq.56.3.211

Dadpay, A., \& Heywood, J. S. (2006). Mixed oligopoly in a single international market. Australian Economic Papers, 45(4), 269-280. https://doi.org/10.1111/j.1467-8454.2006.00292.x

De Fraja, G., \& Delbono, F. (1989). Alternative strategies of a public enterprise in oligopoly. Oxford Economic Papers, 41(2), 302-311.

Debashis, P., \& Mark D. W. (1998). Mixed oligopoly, privatization, and strategic trade policy. Southern Economic Journal, 264-281.

Fershtman, C. (1990). The interdependence between ownership status and market structure: The case of privatization. Economica, 319-328. https://doi.org/10.2307/2554937

Fjell, K., \& Heywood, J. S. (2002). Public Stackelberg leadership in a mixed oligopoly with foreign firms. Australian Economic Papers, 41(3), 267-281. https://doi.org/10.1111/1467-8454.00164

Fjell, K., \& Pal, D. (1996). A mixed oligopoly in the presence of foreign private firms. Canadian Journal of Economics, 737-743. https://doi.org/10.2307/136260

Giovanni, D. F., \& Flavio, D. (1990). Game theoretic models of mixed oligopoly. Journal of Economic Surveys, 4(1), 1-17. https://doi.org/10.1111/j.1467-6419.1990.tb00077.x

Harris, R. G., \& Wiens, E. G. (1980). Government enterprise: An instrument for the internal regulation of industry. The Canadian Journal of Economics/Revue Canadienne d'Economique, 13(1), 125-132. https://doi.org/10.2307/134624

Helmuth, C., Maurice, M., \& Jacques-François, T. (1991). Mixed oligopoly with differentiated products. $\begin{array}{llll}\text { International Journal of Industrial Organization, } & 9(1), \quad 43-53 .\end{array}$ https://doi.org/10.1016/0167-7187(91)90004-5

Heywood, J. S., \& Ye, G. (2009). Privatisation And Timing In A Mixed Oligopoly With Both Foreign And $\begin{array}{lllll}\text { Domestic Firms. Australian } & \text { Economic }\end{array}$ https://doi.org/10.1111/j.1467-8454.2009.00379.x

Matsumura, T., \& Kanda, O. (2005). Mixed oligopoly at free entry markets.Journal of Economics, 84(1), 27-48. https://doi.org/10.1007/s00712-004-0098-z

Merrill, W., \& Schneider, N. (1966). Government firms in oligopoly industries: A short-run analysis. Quarterly Journal of Economics, 80(3), 400-412. https://doi.org/10.2307/1880727

Myles, G. (2002). Mixed oligopoly, subsidization and the order of firms' moves: An irrelevance result for the general case. Economics Bulletin, 12(1), 1-6.

Nilssen, T., \& Sørgard, L. (2002). A public firm challenged by entry: Duplication or diversity? Regional Science and Urban Economics, 32(2), 259-274. https://doi.org/10.1016/S0166-0462(01)00079-5

Pal, D., \& White, M. D. (2003). Intra-industry trade and strategic policy police in the presence of public firms. International Economic Journal, 17(4), 29-41.

Poyago-Theotoky, J. (2001). Mixed oligopoly, subsidization and the order of firms' moves: An irrelevance result. Economics Bulletin, 12(3), 1-5.

Sertel, M. R. (1988). Regulation by participation. Journal of Economics, 48(2), 111-134. https://doi.org/10.1007/BF01234606

White, M. D. (1996). Mixed oligopoly, privatization, and subsidization. Economics Letters, 53(2), 189-195. https://doi.org/10.1016/S0165-1765(96)00916-0

\section{Copyrights}

Copyright for this article is retained by the author(s), with first publication rights granted to the journal.

This is an open-access article distributed under the terms and conditions of the Creative Commons Attribution License (http://creativecommons.org/licenses/by/4.0/). 